Brazilian Journal of Microbiology (2009) 40: 455-457

ISSN 1517-8382

\title{
POTENTIALLY PATHOGENIC MYCOPLASMAS IN THE EXTERNAL EAR CANAL OF CLINICALLY NORMAL CATTLE IN SOUTHEAST BRAZIL: FIRST REPORT
}

\author{
Sandra Batista dos Santos ${ }^{1}$; Elmiro Rosendo do Nascimento ${ }^{2 *}$; João Luiz Horácio Faccini ${ }^{3}$; Maria Lúcia Barreto ${ }^{4}$; \\ Virginia Léo de Almeida Pereira ${ }^{2}$ \\ ${ }^{1}$ Pós-Graduação em Ciências Veterinárias, Universidade Federal Rural do Rio de Janeiro, Seropédica, RJ, Brasil; \\ ${ }^{2}$ Departamento de Saúde Coletiva Veterinária e Saúde Pública, Universidade Federal Fluminense, Niterói, RJ, Brasil; \\ ${ }^{3}$ Departamento de Parasitologia Animal, Instituto de Veterinária, Universidade Federal Rural do Rio de Janeiro, Seropédica, \\ RJ, Brasil; ${ }^{4}$ Departamento de Imunobiologia, Universidade Federal Fluminense, Núcleo de Animais de Laboratório, \\ Universidade Federal Fluminense, Niterói, RJ, Brasil
}

Submitted: September 19, 2008; Returned to authors for corrections: November 12, 2008; Approved: May $04,2009$.

\begin{abstract}
Mycoplasmas were searched in the ear canal flushing of 60 bovine in Brazil. The prevalence obtained was $80 \%$. The percentages of typified species were $12.5 \%$, for M. alkalenses; $2.1 \%$, M. arginini; $8.35 \%, M$. bovirhinis; 2.1\%, M. bovis; 25.0\%, M. conjunctivae; 14.6\%, M. mycoides subsp. mycoides LC and 10.4\% M. capricolum.
\end{abstract}

Key words: Mollicutes, bovine, external ear canal, immunoperoxidase.

In the prokaryotes (Class Mollicutes), mycoplasma is the smallest and simplest self-replicating known bacteria that lack a peptidoglycan layer and have a low guanine plus cytosine content in the genome. Mycoplasmas are widespread in nature as parasites of humans, mammals, reptiles, fish, arthropods, and plants $(14,15)$. These organisms have limited metabolic options for replication and survival. Consequently, they are extremely fastidious in their nutritional requirements (14). Many mycoplasmas are pathogenic to animals, humans and plants and they are, therefore, of great concern in human and veterinary medicine as well as in plant pathology. These organisms are often host-specific, and ruminants, especially cattle, harbour a number of different species $(5,15)$. In livestock production these organisms cause economical losses, being Mycoplasma mycoides subsp. Mycoides SC, the etiological agent of Contagious Bovine Pleuropneumonia, that is from a global point of view, one of the most serious bacterial disease of animals. Others species like $M$. bovis, $M$.

*Corresponding Author. Mailing address: Universidade Federal Fluminense-Faculdade de Medicina Veterinária - Dept. de Saúde coletiva Veterinária e Saúde Pública - Rua Vital Brasil n. 64. Santa Rosa Cep. 24020-150, Niterói-RJ, Brasil. Tel.: (21) 26299536. Fax: E-mail: elmiro@,vm.uff.br 
Santos, S.B. et al.

bovigenitalium, M. alkalescens, $M$. dispar, M. conjunctivae and $M$. capricolum are capable of infecting cattle and causing mastitis, arthritis, respiratory disease, disorders in the reproductive system and infectious keratoconjunctivitis $(2,8,9,10,13)$. M. bovirhinis is a troublesome agent as a secondary invader in respiratory disease, besides being considered the most commonly isolated mycoplasma from the nasal cavity of cattle with respiratory disease $(11,15) . M$. bovigenitalium is closely related to $M$. bovis biochemical and culturally. M. bovis is a pathogen isolated from otitis media and otitis interna that occur in both dairy and beef cattle (5). M. alkalescens was first isolated in cattle in Japan from the lungs of calves with respiratory disease in 1991 (10). In Brazil many mycoplasmas species have been isolated in cattle and goats herds $(1,2,6,11,12)$. In spite of few cattle mycoplasmosis studies in Brazil, M. bovirhinis was isolated in vaginal mucus of heifers with symptoms of reproductive disorders, infertility and granular vulvitis. M. bovis was isolated in cases of mastitis in cows $(11,13)$. As to goats mycoplasmosis, the species isolated from outbreaks in Brazil were M. mycoides subsp. capri and M. mycoides subsp. mycoides LC, being the disease characterized by pneumonia and others respiratory symptoms, keratoconjunctivitis and septic arthritis (9). M. agalactiae was isolated in two outbreaks occurred in the Northeastern of Brazil, with the signs of mastitis and agalactia in which the kids yielded fever, lameness, painful joints, anorexia, arthritis and conjunctivitis (2). Reports on infectious keratoconjunctivitis (IKC) also happened from goats flocks in Pernambuco and São Paulo States $(1,6)$. IKC is a disease commonly known as pink-eye, a contagious disease of domestic ruminants, localized in the eyes and characterized by inflammation of the conjunctiva and cornea, caused by $M$. conjunctivae. Although cases of infectious keratoconjunctivitis by $M$. conjunctivae, have not still been described in cattle in this country. The goat's external ear canal can be an unusual source of mycoplasmas, including pathogenic species, where mycoplasmas have been found associated with ear mites $(3,4,5,13)$. In cattle these conditions had not been evaluated yet. The objective of this study was to register the isolation of pathogenic mycoplasmas species in the external ear canal of clinically normal cattle slaughtered for human consumption.

Flushing were carried out in the external ear canal of 60 bovine at slaughter time in an abattoir of Rio de Janeiro State, Southeastern, Brazil. Sterilized syringes $(60 \mathrm{ml})$ loaded with buffer solution (PBS, $\mathrm{pH}$ 7.2) were used for the cattle ear canal flushing. The obtained samples were diluted in the glycerol (1:2) and stored at $-20^{\circ} \mathrm{C}$ until use. These samples were diluted up to $10^{-5}$, inoculated in liquid and solid modified Hayflick's medium and incubated at $37^{\circ} \mathrm{C}$ for $2-3$ days. Finally, the plates were transferred into a jar to attain a microaerophilia condition. The agar plates were observed every two days under stereomicroscope for the presence of typical colonies "fried-egg". Typical colonies were typified by the indirect immunoperoxidase test (7). Paper discs soaked in hyperimmune rabbit sera against $M$. arginini, $M$. bovis, $M$. conjunctivae, M. mycoides mycoides LC, M. bovirhinis, M. alkalescens, $M$. capricolum, $M$. verecundum and $M$. gallisepticum. The prevalence of Mycoplasma spp. in the in the external ear canal of the studied cattle was $80 \%(48 / 60)$. Concomitantly, Raillietia spp. was found in the ear of most of these animals. The percentage of Mycoplasma species isolated in the flushing ear canals of these bovine were $12.5 \%$ (6/48) for M. alkalenses; 2.1\% (1/48), M. arginini; 8.35\% (4/48), M. bovirhinis; 2.1\% (1/48), M. bovis; 25.0\% (12/48), M. conjunctivae; $14.6 \%$ (7/48), M. mycoides subsp. mycoides LC and $10.4 \%(5 / 48)$ for $M$. capricolum. In this study the animals were clinically normal for mycoplasmosis and, although some presented subclinical otitis, which is relatively 
common in raillietiosis cases. The results confirm that the cattle's ear canal is also a mycoplasmas source, including pathogenic species.

\section{ACKNOWLEDGMENTS}

We wish to thank the Conselho Nacional de Desenvolvimento Científico e Tecnológico - CNPq for financial support during the development of the research.

\section{RESUMO}

\section{Micoplasmas potencialmente patogênicos no canal auditivo de bovinos clinicamente sadios no Sul do Brasil: \\ primeiro relato}

Foram pesquisados micoplasmas no conduto auditivo de 60 bovinos no Brasil. A prevalência obtida foi de $80 \%$. A porcentagem das espécies tipificadas foi de M. alkalenses, 12,5\%; M. arginini, 2,1\%; M. bovirhinis, 8,35\%; M. bovis, 2,1\%; M. conjunctivae, 25,0\%; M. mycoides subsp. mycoides LC, $14,6 \%$ e $M$. capricolum, 10,4\%.

Palavra chave: Mollicutes, bovinos, conduto auditivo externo, immunoperoxidase

\section{REFERENCES}

1. Almeida, N.J.B.; Sá, F.B.; Buzinhani, M.; Timenetsky, J.; Mota, R.A.; Almeida, M.Z. (2004). Ocorrência de Mycoplasma conjunctivae em ovinos sadios e com ceratoconjuntivite infecciosa, no estado de Pernambuco. Arq. Inst. Biol., São Paulo, 71 (1):79-81.

2. Azevedo, E.O.; Alcântara, M.D.B.; Nascimento, E.R.; Tabosa, I.V.; Barreto, M.L.; Almeida, J.F.; Araújo, M.D’O.; Rodrigues, A.R.O.; Riet-Correa, F.; Castro, R.S. (2006). Contagious agalactia by
Mycoplasma agalactiae in small ruminants in Brazil: first report. Braz. J. Microbiol., 37:576-581.

3. Cottew, G.S.; Yeats, F.R. (1982). Mycoplasmas and mites in the ear of clinically normal goats. Aust. Vet. J. 59(3): 77-81.

4. Damassa, A.J. (1990). The ear canal as a culture site for demonstration of mycoplasmas in clinically normal goats. Aust. Vet. J., 67: 267-269.

5. Francoz, D.; Fecteau, G.; Desrochers, A.; Fortin, M. (2004). Otite media in dairy calves: A retrospective study of 15 cases (1987 to 2002) Can. Vet. J. 45: 661-666.

6. Gregory, L.; Cardoso, M.V.; Birgel Jr., E.H.; Teixeira, S.R.; Souza, R.M.; Pacheco, W.A.; Birgel, E.H.; Benesi, F.J. (2003). Surto de ceratoconjuntivite infecciosa dos caprinos causada por Mycoplasma conjunctivae em caprinos adultos, criados no Estado de São Paulo. Arq. Inst. Biol., São Paulo, 70(2):179-181.

7. Imada, Y.; Uchida, I.; Hashimoto, K. (1987). Rapid identification of Mycoplasma by indirect immunoperoxidase test using small square filter paper. J. Clin. Microbiol., 25:17-21.

8. Kudo, R.; Hiroshima, S.; Tsukahara, K.; Sakamoto, T.; Hirano, T.; Nakata, Y. (1994). Isolation of Mycoplasma alkalescens and Mycoplasma bovis from the nasal swabs of calves with pneumonia, $J$. Jpn. Vet. Med. Assoc., 47:311-314.

9. Nascimento, E.R.; Nascimento, M.G.F.; Freundt, E.A.; Andersen, H. (1986). Isolation of Mycoplasma mycoides from outbreaks of caprine mycoplasmosis in Brazil. Br. Vet. J., 142: 246-257.

10. Nascimento, M.G.F.; D'angelis, F.H.F.; Nascimento, E.R; Resende, O.A.; Lignon, G.B. (1998). Mycoplasma bovirhinis em muco vaginal de novilhas. Revista Brasileira de Medicina Veterinária. 20(5): $210-$ 214.

11. Nascimento, M.G.F.; D'angelis, F.H.F.; Nascimento, E.R.; Resende, O.A. (2005). Envolvimento de micoplasmas em vacas com distúrbios reprodutivos. Acta Scientia Veterinariae, 33(2): 195-199.

12. Pretto, L.G.; Muller, E.E.; Freitas, J.C.; Mettifogo, E.; Buzihani, M.; Yamaguti, M.; Salvador, R. (2001). Mastite bovina por Mycoplasma bovis em rebanhos leiteiros. Pesqui. Vet. Bras. 21(4): 143-145.

13. Ribeiro, V.R.; Nascimento, E.R.; Faccini, J.L.H.; Nascimento, M.G.F.; Lignon, G.B. (1995). Presença de Micoplama em exemplares de Raillietia caprae coletados do conduto auditivo externo de caprinos. Revista Brasileira de Medicina Veterinária. 17(3): 122-124.

14. Rottem, S. (2003). Interactions of mycoplasmas with host cells. Phys. Rev. 83: 417-432.

15. Whitfoord, H.W.; Rosenbusch, R.F.; Lauerman, L.H. (1994). Mycoplasmosis in Animals, Laboratory Diagnosis, Iowa State University, Ames, 150p. 